Received: 30 July 2021 Accepted: 23 December 2021

\title{
The Resistance to Mainstream Assumptions about Retribution in Job and Tobit as Theologically Positive Deviance
}

\section{Katherine Southwood ${ }^{1}$}

\begin{abstract}
This article uses material from organizational studies and medical anthropology and sociology to address the value of the idea that bodily dysfunction or illness depart from a norm of health. It argues that examples of positive deviance can be found in the books of Tobit and in Job. Positive deviance describes behavior that notably departs from expected norms, albeit in a direction that a referent group finds positive. In much of the Hebrew Bible, there is a tight connection between the ideas of wrongdoing, bodily suffering, and retribution. However, the books of Tobit and Job are examples of a departure away from this norm. In Job and Tobit the portrayal of circumstances in the text depart from expected norms with a view to encouraging the referent group (i.e., audiences) towards a positive assessment of the departure. The character Tobit, in line with dominant thought about retribution assumes his blindness is a result of some inadvertent or inberited sinfulness. However, Tobit's characterisation and dramatic irony prevents audiences agreeing with Tobit's assessment of circumstances. Similarly, the advice of Job's friends betrays their assumption that his physical condition must be retribution for wrongdoing. However, Job's characterisation and dramatic irony prevents audiences agreeing with bis friends. More shockingly, the character Yabweh departs from the expected role and becomes a deviant actor. Through resisting simplistic assessments of somatic distress as caused by retribution for wrongdoing, both books are examples of positive deviance that encourage audiences towards more positive norms.
\end{abstract}

Keywords: Deviance; Tobit, Job; Retribution; Body

Although the study of deviant behavior has often been linked with criminality, significant parts of the literature focus on questions concerning society. In his influential sociological study of outsiders,

${ }^{1}$ Katherine Southwood, University of Oxford, UK. E-mail: katherine.southwood@theology.ox.ac.uk. 
for example, Becker argued that deviance was something created by society's rules. Becker argues that,

social groups create deviance by making the rules whose infraction constitutes deviance, and by applying those rules to particular people and labelling them as outsiders. From this point of view, deviance is not a quality of the act the person commits, but rather a consequence of the application by others of rules and sanctions to an "offender."2

Becker's approach to deviance in this argument is relativistic, or reactive: rather than criminalising the so-called deviant he shifts our attention towards social context. ${ }^{3}$ This also directs our attention to group norms. We cannot straightforwardly assume that somebody who breaks group rules must be morally culpable because this depends on the quality of the group's rules and norms. This observation is a helpful starting point when thinking about the positive sides of deviance. In the last twenty years, sociologists in health sciences, organisation, and management studies have increasingly discussed the importance of positive deviance. Positive deviance "involves people behaving in ways that notably depart from expected norms, albeit in a direction that some group of others (i.e., a referent group) finds positive." " Therefore, positive deviance can be thought of as norm-defying but, paradoxically, also a socially desirable quality.

It is important to remember here the relevance of labels and contexts. As Lavine points out "terrorists, in the eyes of one referent

\footnotetext{
${ }^{2}$ Howard Saul Becker, Outsiders: Studies in the sociology of deviance (New York: London: Free Press; Collier Macmillan, 1963), 8-9.

3 There are various methods for considering deviance in sociology, alongside relativism. Approaches include "functionalism" which emphasises the importance of social function; "absolutism" which evaluates deviance against seemingly universal values; "reactivism" which requires an audience to deem a behaviour deviant; "normativism" which views deviance as breaking social norms; and "statistical deviance," where deviance is about minorities. Marshall B. Clinard and Robert F. Meier, Sociology of Deviant Behavior (Belmont, CA: Thomson/Wadsworth, 2004).

4 Marc Lavine, "Positive Deviance: A Metaphor and Method for Learning from the Uncommon," in The Oxford Handbook of Positive Organizational Scholarship, (Oxford: Oxford University Press, 2011), 1014. Cf. Gretchen. M. Spreitzer, and Scott Sonenshein, "Positive Deviance and Extraordinary Organizing," in Positive Organizational Scholarship: Foundations of a New Discipline (San Francisco: BerrettKohler), 207-224.
} 
group, are freedom fighters to another." ${ }^{5}$ Positive deviance is particularly helpful when norms are problematic. This is because in rejection of norms, for example, in failing to align with organisational expectations, "deviants are often the source of innovation, energy, and change." The potential for positive deviance to introduce revolutionary transformative energy is also demonstrated in detail in Pascale, Sternin and Sternin's case-studies showing how it was used to solve exceptionally difficult problems including childhood malnutrition in Vietnam, MRSA hospital infections, and infant mortality in Pakistan. ${ }^{7}$ Therefore, although the idea of positive deviance may at first sound oxymoronic, if norms are unhelpful and causing intractable problems then it can be an innovative, problemsolving resource. Ultimately, where positive deviance successfully solves problems, it may result in shifting former unhelpful attitudes and practices towards more positive norms.

Positive deviance is a useful tool that is often evoked in organisational studies concerning healthcare to change practice. ${ }^{8}$ However, it is also a useful tool for thinking about the negative impacts of health norms and wellbeing expectations. Specifically, positive deviance may be evoked in response to stigma associated with illnesses and disability. This stigma is particularly pronounced when bodily dysfunction (defined for the purposes of this article as anything that deviates from "health") is interpreted by connecting it

\footnotetext{
${ }^{5}$ Lavine, "Positive Deviance," 2021. Positive deviance is to be distinguished from tempered radicalism (which can also be used to describe people do not act in normative ways) because this does not always involve change, merely ambiguity and refraining from action. In contrast, positive deviance does involve action and change.

${ }^{6}$ Judith L. Walls and Andrew J. Hoffman, "Exceptional Boards: Environmental Experience and Positive Deviance from Institutional Norms," Journal of Organizational Behavior 34, (2013): 266.

${ }^{7}$ Richard T. Pascale, Jerry Sternin, and Monique Sternin, The Power of Positive Deviance (Boston: Harvard Business School Press, 2010).

8 Bernadette Mazurek Melnyk and Tim Raderstorf, Evidence-based Leadership, Innovation, and Entrepreneurship in Nursing and Healthcare: A Practical Guide to Success (New York: Springer, 2021). Anat Gesser-Edelsburg, Ricky Cohen, Adva Mir Halavi, and Mina Zemach, "Motivating Healthcare Professionals (nurses, nurse assistants, physicians) to Integrate new Practices for Preventing Healthcare-associated Infections into the Care Continuum: Turning Positive Deviance into Positive Norms," BMC Infectious Diseases 21, (2021): 495. Alexandre R. Marra, Luciana Reis Guastelli, Carla De Araújo Manuela Pereira, Dos Santos, Jorge L. Saraiva, Luiz Carlos R. Lamblet, Moacyr Silva Jr, Gisele De Lima, et al. "Positive Deviance: A new Strategy for Improving Hand Hygiene Compliance," Infection Control and Hospital Epidemiology 31, (2010): 12-20.
} 
with deviancy. 'This is a very common connection. For example, Lloyd observes that "the boundary between the criminal and the sick is ... deeply contentious' because 'not only are there powerful preconceptions of what is normal at work ...but the type of abnormality in question may be deeply controversial." ${ }^{10}$ Put slightly differently, Gabe and Monaghan argue that "medicalization is often associated with the control of deviance and the ways in which deviant behaviours that were once defined as immoral, sinful or criminal have been given medical meanings." 11 This is interesting because of questions related to agency and responsibility. Positive deviance interrupts the simplistic expectation that constructs good health as a norm and bad health with deviance and, therefore, stigma.

Uncoupling the simplistic binary that "healthy $=$ norm $/$ ill $=$ deviance + stigma" is helpful. This is because although stewarding the body responsibly is important, we must also acknowledge that sometimes people do not possess agency to control their health. For example, sometimes lung cancer is caused by lack of responsibility through heavy smoking but not every person who develops lung cancer has smoked. The latter group have little agency so the question "how much did you smoke?" would be inappropriate and heartless. However, positive deviance through interrupting the aforementioned binary has not yet changed the norm of health as an

\footnotetext{
${ }^{9}$ The categories of illness and health are not as stable as might be supposed because what counts as sickness various over time. For example, the ancient Greeks thought of love as a burning sensation or fever. (G. E. R Lloyd, In the Grip of Disease: Studies in the Greek Imagination [Oxford: Oxford University Press, 2003]:239). Similarly, until 1973 homosexuality was deemed an illness by the American Psychiatric Association. As these examples illustrate, the way we think about health and illness norms is laden with (sometimes destructive) ideologies and other cultural values. Even corporeal sensations are interpreted along the lines of what is socially meaningful. As medical Anthropologist Throop demonstrates concerning pain in Yap, "it is not that pain hurts less here. It does not, nor do wounds reopened by the strain of continued work heal more quickly. The pain simply matters less." (C. Jason Throop, Suffering and Sentiment: Exploring the Vicissitudes of Experience and Pain in Yap. [Berkeley: University of California Press, 2010]: 159.) In order to emphasise the significance of cultural influences on our interpretation of sickness, medical anthropologists often distinguish between "illness" and "disease" with the latter being a pathological condition recognised by biomedicine and the former being more subjective. Given the importance of recognising social values in assessment of sickness and disability, this article will use the terms "illness" or "bodily dysfunction" and synonyms rather than "disease." ${ }^{10}$ Lloyd, In the Grip, 244.

${ }^{11}$ Jonathan Gabe and Lee F. Monaghan. Key Concepts in Medical Sociology (Los Angeles; London: SAGE, 2013): 59 .
} 
expectation in many places. Evidence for this is plentiful. For example, Tomlinson points out with respect to the stigmatised condition of obesity, public assumptions are often that people who are obsese are "careless, or immoral lacking in self-respect "fatties" who, despite their better knowledge, continue to criminally abuse their "freedom" ... and the irrational fatties, ... guilty of "fatlogic." 12 Medical Sociologist Lupton makes a similar point, arguing that "to be ill in contemporary societies is already to be marginalized, because illness is treated as a bodily state which challenges expectations about the well-functioning, productive citizen." ${ }^{13}$ Similar examples connecting deviance and sickness are not hard to find. Gotto helpfully collects a range of examples together, observing that "in the mid-19th century, outbreaks of cholera were blamed on Irish immigrants in England and the United States .... In the early 20th century, epidemics of plague in California were blamed on Chinese and Mexican immigrants. Epidemics of venereal disease have historically been attributed to 'loose women.' At the beginning of the 1980s, the spread of AIDS was blamed on gay men, Haitians, and haemophiliacs." "14 The list of examples provided here is by no means exhaustive, but it is perhaps enough to illustrate the scope and persistence of unhelpful casual connections between illness, assumed deviance through a failure to responsibly steward the body, and

\footnotetext{
${ }^{12}$ Jonathan Tomlinson, "Power, Prejudice and Professionalism: Fat Politics and Medical Education," in Handbook of Primary Care Ethics (Boca Raton, FL: CRC Press, 2017): 160.

${ }^{13}$ Deborah Lupton, Fat (Abingdon; New York: Routledge, 2012): 50. The connection between illness and deviance is not just relegated to contemporary societies, as Lupton's argument might imply. Ancient societies also made this connection, often in a much more pronounced way. Sontag illustrates the point with regard to Classical material by pointing out that, "the speculation of the ancient world made disease most often an instrument of divine wrath. Judgement was meted out to a community (the plague in book 1 of the Iliad that Apollo inflicts on Achaeans in punishment for Agamemnon's abduction of Chryses' daughter; the plague in Oedipus that strikes Thebes because of the polluting presence of the royal sinner) or a single person (the stinking wound in Philoctetes' foot).... For the Greeks, disease could be gratuitous or it could be deserved (for a personal fault, a collective transgression, or a crime of one's ancestors)." Susan Sontag, Illness as Metaphor (New York: Farrar, Straus and Giroux, 1978), 3940, 43. The connection between illness and retribution, so often implied through illness metaphors, that Sontag critiques in her work is very clear in this quotation.

${ }^{14}$ Antonio Gotto, "Suffering, medicine, and the book of Job," Journal of Religion, Disability \& Health 16 (2012): 423 .
} 
stigma. It also shows the resistance to this connection among medical sociologists and anthropologists.

Perhaps it is not surprising to find that in much of the Biblical material this connection between deviance and bodily retribution is also very strong. Ideas about retribution persist across genre and date. Although regularly thought of as "Deuteronomic," perhaps because of the highly somatic nature of the curses listed in Deuteronomy 28, the link between retribution and bodily dysfunction persists in many of the Psalms, Proverbs, and in biblical narrative (Dt. 28:21-22, 27-28). Sometimes this connection is obvious and almost mechanistic, e.g., "he who digs a pit will fall into it" (Prov. 26:27). Other times deviance and somatic dysfunction is implied, for example through confessions of guilt in penitential prayer (e.g., Ps. 38:3, 5). ${ }^{15}$ Southwood demonstrates the widespread connection between the idea of illness and wrongdoing in the Hebrew Bible, noting several instances of bodily retribution for wrongdoing including:

the diseases on Pharaoh and his household on account of Abram's wife-sister deception (Gen 12:17); the striking blind of the men threatening Lot's house (Gen. 19:11); the closing of wombs in Abimelech's household again because of Abraham's wife-sister trickery (Gen 20:17-18); plagues and death of the Egyptian first-born on account of the genocide and forced labour of Hebrews (Exod. 7-11); Miriam's infection of צרעת on account of her and Aaron's speaking out against Moses's intermarriage with an Ethiopian woman (Num. 12:9-10); various occasions in Numbers when Yahweh threatened the Israelites with illness during their rebellions against Moses and Aaron (Num. 14:11-12, 36-37;

\footnotetext{
${ }^{15}$ Concerning penitential prayer, refer to Mark J. Boda, Daniel K. Falk, and Rodney A. Werline (eds.), Seeking the Favor of God: The Origins of Penitential Prayer in Second Temple Judaism, vol. I (Atlanta, Ga.: Society of Biblical Literature, 2006); Richard J. Bautch, Developments in Genre between Post-exilic Penitential Prayers and the Psalms of Communal Lament (Atlanta: Society of Biblical Literature, 2003); Judith H. Newman, Praying by the Book: The Scripturalization of Prayer in Second Temple Judaism (Atlanta: Scholars Press, 1999); Rodney A. Werline, Penitential Prayer in Second Temple Judaism: The Development of a Religious Institution (Atlanta, Ga.: Scholars Press, 1998).
} 
17:12-15; 25:3-9, 17-18; 31:16); the Philistines' tumours upon capturing in the ark (1 Sam. 5:6-6:12); the unfaithful king Jeroboam's child dies in Yahweh's manoeuvre to wipe his house out (1 Kgs 14:10-14); Yahweh refuses to heal Ahaziah because he consulted with Beelzebub (2 Kgs 1:16); greed incites צרעת in Gehazi as punishment (2 Kgs 5:26-27); the pride of King Uzziah causes him to get צרעת (Chr. 26:1620); Jehoram gets an incurable illness on account of deserting Yahweh (2 Chr. 21:14-15); and David's census annoys Yahweh, so he is punished with a plague resulting in the death of 70,000 people (2 Sam. 24:10-15; 1 Chr. 21:7-14). ${ }^{16}$

However, the connections between wrongdoing and corporeal retribution also persist beyond the boundaries of the Biblical corpus. Hogan notes this trend in Second Temple Judaism. Hogan suggests that the three books of 1 Enoch (Watchers, Similitudes, and the Epistle of Enoch) all deal with sin as a cause of illness. Jubilees 10 also deals with the sin of the fallen angels and the sin of mankind as the cause of suffering and illness. The Testaments of the 12 Patriarchs connect sin to the onset of illness (T Reuben; T Gad. 5:11). In the Genesis Apocryphon, three factors bring about the affliction of Pharaoh and his household: his sin in regard to Sarah, the evil spirit who brings about the affliction, and God who is said to have struck the Egyptians with pestilence. Similarly, in the Prayer of Nabonidus at Qumran we may presume by the mention of Nabonidus confessing and being forgiven that sin is responsible for his illness. Likewise, in Ben Sira while justifying the role of physicians and medical remedies, the ill person is encouraged to pray to God first then to acknowledge one's faults and make a generous sacrifice (38:15). In addition, the sins of Geliodorus (2 Macc. 3) and Antiochus IV (4 Macc. 9) bring on their afflictions. In 1 Corinthians a lack of charity leads to the illness of community members. Philo of

\footnotetext{
${ }^{16}$ Katherine E. Southwood, Job's Body and the Dramatised Comedy of Moralising (Taylor and Francis, 2021), 6 n. 20. Some of these examples include mention of the condition צרעת as punishment for wrongdoing. This term has purposefully been left untranslated. The condition may afflict humans, but also buildings (Lev. 13:49). It may be connected to ritual uncleanness and the inability to participate in cultic ritual.
} 
Alexandria connects illnesses with sin and lack of virtuous living. (De Sacrificiis 70-71). Likewise, Josephus attributes the fatal illness of Herod to his wickedness (Ant. XVII 168-171), as he does the fatal illness of Catullus to his misdeeds (J.W. VII 451-453; Hogan 1992:145). ${ }^{17}$

The evidence for demonstrating the prevalence of the connection between wrongdoing and bodily retribution is plentiful. This makes it all the more striking that, as will be argued, examples such as the stories of Tobit and Job exist where connections between deviance and somatic retribution, are not made or are even questioned. Given the prevalence of assumptions about illness and retribution, even in current times where biomedicine enables us better to understand causality, early material that questions the connection between bodily dysfunction and deviance is very progressive. In these texts, theologically positive deviance is found in the presentation to the audience of the possibility to reject, or to question, traditional connections between wrongdoing and somatic retribution.

\section{Positive deviance in Tobit and Job.}

Two key examples that might be helpfully framed as positive deviance away from common connections made in the Biblical material between bodily dysfunction and retribution (and therefore implied deviance), occur in Job and in Tobit. These are examples wherein the portrayal of circumstances and reactions to them in the text (rather than the bebaviour of the main character) depart from expected norms with a view to encouraging the referent group (i.e., audiences) towards a positive assessment of the departure from the expected norm. Framing the discussion through the heuristic lens of positive deviance is particularly helpful because it helps us to think critically about norms and their value. ${ }^{18}$ The notion of somatic retribution as something of a norm within Yahwism may, in some cases, be helpful. For example, it may encourage Yahwistic communities towards loyalty to the deity. But, as a norm somatic

${ }^{17}$ Larry P. Hogan, Healing in the Second Temple Period (Freiburg: Universitäts Verlag, 1992). 
retribution could also be problematic when applied to a person who has done nothing to warrant their condition, as in the cases of Job and Tobit. This is because the norm has the potential to provoke judgemental assumptions from others in the text resulting in the secondary illness of stigmatization by others, or even the assumption of one's own wrongdoing.

In both Tobit and Job, the physical health of the main protagonist is compromised without explanation. Dramatic irony prevents Job and his friends from being able to explain that the Accuser has been permitted by Yahweh to strike him. Similarly, for Tobit a random and "remarkable double hit" of bird droppings impair the character's sight. ${ }^{19}$ The fact that the audience knows what the main characters do not is a key part of the way that audiences are encouraged to think about, and question, the value of somatic retribution for wrongdoing as a norm. Dramatic irony encourages audiences towards a more theologically positive deviance which questions the norm. As we will discuss, in the books of Job and of Tobit the impairment to the main character's body is not portrayed as retribution.

\section{Positive deviance in Tobit.}

Tobit's interpretation of his own blindness demonstrates a clear commitment to the idea of retribution, as he pleads "do not punish me for my sins, and for my unwitting offenses, and those that my ancestors committed before you" (Tob. 3:3-6). The emphasis throughout his prayer, in fact, is on the sinfulness both of himself and of his ancestors which he interprets as culminating in exile. ${ }^{20}$ This is a very marked statement of a norm: the connection in much of the Biblical and Second Temple period material between bodily dysfunction and retribution. Tobit's connection here has caused some scholars to conclude that Tobit has a strongly Deuteronomic

\footnotetext{
19 David McCracken, 1995. "Narration and Comedy in the Book of Tobit," Journal of Biblical Literature 114 (1995): 402.

${ }^{20}$ This interpretation of exile as punishment through penitential prayer is not unusual. For example, a similar perspective emerges quite clearly in Nehemiah 9 and in prayers relating to the breaking of Yhwh's ‘commandments' (cf. Tob. 3:5; Ezr. 9:10, 14; Neh. 1:7; 9:16, 34).
} 
perspective. ${ }^{21}$ As Hicks-Keeton argues, “Tobit's first prayer (3:1-6) reveals a Deuteronomic theology of sin and punishment ... Tobit laments Israel's misfortunes and his own: he interprets his present circumstances through a lens of national relations with God."22 This persuasive argument, which is well-supported by the textual evidence is helpful because it shows the prevalence of the norm. ${ }^{23}$ An immediate connection is made by the character in front of the audience, or referent group, familiar with the norm between wrongdoing and retribution, or ask Lloyd puts it "the criminal and the sick." ${ }^{24}$ In many ways, Tobit's interpretation of his blindness embodies the norm.

However, where positive deviance emerges before the audience, or the referent group, is through demonstrating the problems associated with this norm. As Kiel argues, the story draws "a close connection between act and consequence" which "is shown to be problematic." 25 The way the connection is interrupted in Tobit is through Tobit's zealously pious characterisation, which exaggerates the norm by depicting it in a very mechanistic and simplistic way. As Kiel points out, Tobit's words “are a sapiential boilerplate, stressing the importance of righteousness, almsgiving, and endogamy, all of which are underpinned by a straightforward sense of retribution."26 Similarly, the way Tobit uses the term Mıø0ó (literally "wages," and figuratively "reward") is evidence of his mechanistic reasoning when it comes to retribution. As Macatangay argues,

The irony in the narrative use of the word $\mu$ rotós is a rhetorical strategy employed to respond to the limitations of

\footnotetext{
21 Alexander A. Di Lella, "A Study of Tobit 14:10 and its Intertextual Parallels," Catholic Biblical Quarterly 71 (2009): 497-506.

22 Jill Hicks-Keeton, “Already/Not Yet: Eschatological tension in the book of Tobit," Journal of Biblical Literature 132 (2013): 101.

${ }^{23}$ Though Weeks is correct to call for caution when using the term 'Deuteronomic' in relation to Tobit. Stuart Weeks, "A Deuteronomistic Heritage in Tobit?" in Changes in Scripture: Rewriting and interpreting authoritative traditions in the second temple period (Berlin: Walter de Gruyter, 2011).

${ }^{24}$ Lloyd, In the Grip, 244.

${ }^{25}$ Micah D. Kiel, The "Whole Trutb:" Rethinking retribution in the book of Tobit (London; New York: T\&T Clark, 2012), 152.

${ }^{26}$ Kiel, The "Whole Truth," 286.
} 
this moral calculus which does not sit as easily in Tobit. On the one hand, a certain strand of the story views $\mu \iota \sigma \theta \dot{s} \varsigma$ literally as wages, applying the term to payment given to a faithful man and never to the reward God gives to a Torahabiding person. On the other hand, the narrative typically connects or associates $\mu$ rodós with bonuses; they are an added compensation that is not necessarily linked to an act or a particular service rendered. ${ }^{27}$

Effectively, Macatangay's argument highlights how simplistic Tobit's view of the world is. The character makes simplistic assumptions about how to live a good life: good deeds, walking in the paths of truth and righteousness, keeping the law, charity, endogamy, and kinship loyalty all lead to rewards, whereas deviance, through departing from these practices, would be met with retribution. These types of assumptions would perhaps have been very familiar to exilic, post-exilic, and diaspora audiences searching for explanations of exile. ${ }^{28}$ However, the exaggeratedly simplified presentation of Tobit's blindness as retribution in the text is an exercise in positive deviance. This is because it invites the referent group, or audience, to question the connection between wrongdoing and somatic retribution.

Indeed, readers are actively encouraged to interpret Tobit in a way that goes against the view of the main character's first-person account through his display of superficiality, when it comes to retribution. As Nowell argues, the story is "motivated by the search for a solution to the problem that the apparent consequence of doing good is not prosperity but suffering" so the apparent consequences of Tobit's fidelity "are blindness and poverty." ${ }^{29}$ Tobit's blindness is a calamity but, contrary to his own assessment of the situation, there

\footnotetext{
${ }^{27}$ Francis Macatangay, "Mıøөó and Irony in the Book of Tobit," Biblica 94 (2013): 583.

${ }^{28}$ As Soll argues, exile "interpreted as a judgment that imparts to the community a lingering background of shame, an abnormal dislocation which renders the time 'out of joint' so long as it endures" so that misfortune is interpreted "as acute manifestations of the chronic condition of exile." Will Soll, "Misfortune and Exile in Tobit: The Juncture of a Fairy Tale Source and Deuteronomic Theology," Catholic Biblical Quarterly 51 (1989): 222.

${ }^{29}$ Irene Nowell, The Book of Tobit: Narrative Technique and Theology, (ProQuest Dissertations Publishing, 1983), 194.
} 
is no straightforward rationale that explains it. $\mathrm{He}$ was enthusiastically attempting to uphold a high level of religious piety by springing up from the family meal to bury a corpse, and yet he also just happened to be in the wrong place at the wrong time (Tob. $2: 4)$. But the way this is narrated in the story provides a springboard for audiences to think carefully and consider the question of deviance and retribution. As Kiel argues, the blindness Tobit experiences "requires a more complex explanation than Tobit washed in the wake of guilt that produced the exile." 30 This is a helpful argument because it allows the referent group, or audiences, space to engage with complexity when somatic dysfunction occurs, or when retribution is too quickly, or without thought, evoked as an explanation. It pushes the referent group towards a perspective more similar to that taken by medical sociologist Lupton in the introduction, where victims of bodily dysfunction are not simplistically to be assigned responsibility for their conditions. ${ }^{31}$

Tobit's characterisation, in particular, encourages audiences to question his simplistically retribution-centred perspective. He argues with his wife, Anna, and makes false assumptions about her integrity (Tob. 2:11-14). He neglects the welfare of his son, according to Anna (Tob. 5:17-22). Dramatic irony enables readers to see what Tobit does not: the angel Raphael accompanying his son on the journey to Media. Even "Azariah” (Raphael) displays dismay upon Tobit's insistence upon kinship loyalty, asking 'why do you need to know my tribe?' (Tob. 5:12). In the eyes of Tobit, he acts as best he can with integrity and according to what Yahweh requires of him. He does not deviate from what is expected of him. Yet, other characters see a different Tobit. As Weeks argues, Tobit's "self-perception sits uncomfortably beside the comments of others" in the narrative. ${ }^{32}$ This encourages referent groups to question the connections that Tobit is making about deviance and retribution. Through doing so, the story itself functions as an example of positive deviance. The

\footnotetext{
${ }^{30}$ Micah D. Kiel, “Tobit's Theological Blindness,” The Catholic Biblical Quarterly 73 (2011): 284.

${ }^{31}$ Lupton, Fat,

32 Weeks, "A Deuteronomistic heritage in Tobit?," 392.
} 
story actively deviates away from a theology that simplistically equates wrongdoing with somatic retribution and it encourages audiences to do so as well. This is a positive move because it shifts audiences to greater recognition of complexity in life and away from the idea that those who suffer must deserve their lot in life because of the idea of retribution. This is an incredibly progressive and forward-thinking example of positive deviance.

The motif of Tobit's blindness is a linchpin upon which the entire question about guilt and deviance turns. Kiel suggests that his blindness is a "theological blindness." 33 But perhaps Tobit is not entirely theologically blind. The problem is not as black and white as this. Rather than being theologically obtuse, Tobit is theologically limited. After all, despite his flaws he is striving to do what he considers to be good, as his name perhaps betrays to readers (טובי). Kiel's argument about Tobit's "straightforward retributive theology" being problematic is more convincing.$^{35}$ Kiel argues that,

The expressions of straightforward retribution, then, in the Book of Tobit are associated only with the blinded title character. The narrator does nothing to ratify Tobit's rhetoric, and the remaining characters do not seem to use it to explain other predicaments in the story (of which there are many). Tobit's blindness is paradigmatic for the action of God hidden in the story. The reader knows more than the characters, which creates irony. ${ }^{36}$.

As Kiel highlights, the discrepancy between the main character, other characters, and the audience's knowledge, is often created through

\footnotetext{
${ }^{33}$ Kiel, “Theological Blindness,” 281. It should be noted that this label takes an ableist perspective, thus criminalizing disability and making blindness into a form of deviance. I return here to question the usefulness of thinking about norms. Although health norms gain social acceptance they are not necessarily, in and of themselves, valuable. For example, as Solomon points out "if most people could flap their arms and fly, the inability to do so would be a disability." Andrew Solomon, Far From the Tree: Parents, Children and the Search for Identity (London: Chatto \& Windus, 2013), 29.

${ }^{34}$ Hicks-Keeton points out the ironic nature of all of the named characters, thus strengthening the case for interpreting Tobit's name as a clue to audiences about his characterization. Hicks-Keeton, "Already/Not Yet," 107.

${ }^{35}$ Kiel, The "Whole Truth," 67.

${ }^{36}$ Kiel, The "Whole Truth," 70.
} 
dramatic irony. In some cases, this is obvious. For example, audiences are made aware of "Azariah's" real identity as Raphael (Tob. 5:4). In other cases, dramatic irony is created by the actions and comments of other characters in the story who function to enable audiences theologically to see what Tobit does not. For

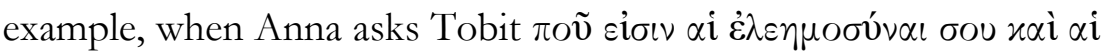

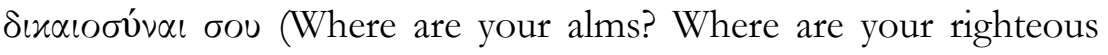
deeds?) at a point in the narrative where he does not have moral authority, having falsely accused her of stealing (Tob. 2:14; cf. Tob. 1:3-9). Enabling the audience, or referent group, to assess for themselves whether or not Tobit's theological perspectives are helpful is a form of positive deviance. Through creating space for audiences to consider, critically, the more mainstream connections between sinfulness and retribution, this popular connection is potentially eroded.

Ironically then, the flaw with Tobit's restricted theological outlook is his eagerness to do what is good. As Efthimiadis-Keith argues, Tobit is "neglectful of his immediate family in favour of himself, money, extended family, the poor and the dead" and this is because of his "obsession with doing good" ${ }^{37}$ Miller also notes the way in which dramatic irony allows audiences to be privy to information that Tobit is not, observing that with regard to Tobias's journey, Tobit exhibits some questionable priorities.

Tobit is not thinking enough about his son's welfare because he allows himself to be distracted by peripheral matters: the money he left with Gabael and Raphael's genealogical pedigree. Tobit's preoccupation with the money is evident at the end of chap. 4 and beginning of chap. 5 when he tells his son about ten talents of silver he deposited with Gabael. Over the span of five verses (4:20-5:3), Tobit mentions

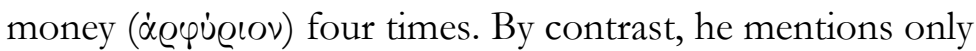
once that his son should find a trustworthy ( $\pi \iota \tau$ ós) guide

\footnotetext{
${ }^{37}$ Helen Efthimiadis-Keith, "Food and Death: An Autobiographic Perspective on Tobit according to one Woman's Binge-eating Disorder," in Tobit and Judith: The Feminist Companion to the Bible (London: Bloomsbury T\&T Clark, 2015): 110.
} 
(5:3). The emphasis should have been the other way around, but money is at the forefront of his mind and has impaired his judgment. ${ }^{38}$

The arguments here are persuasive because they very clearly expose the problem with Tobit's attempts to do good. In some ways his eagerness towards religious piety is rather tragic because it obscures his ability genuinely to engage with those around him. As PortierYoung observes, "the greatest single cause of Tobit's suffering is his inability correctly to perceive and appreciate the extent of his connectedness in this human community." 39 Religious piety in itself is not the problem here, it is the fact that Tobit's religiosity has become so extreme that it prevents him from connecting properly with other people, even close family members. In setting out this paradox, of Tobit doing good but it being destructive, before audiences an example of positive deviance exists in the story of Tobit, exposing Tobit as a "flawed moralist." " It encourages audiences not to be too good, too zealous, too pious and in doing so steers them away from an overly simplistic theology of retribution.

Recalling the theoretical material from earlier, a weight of ancient and modern evidence points towards the persistence of casual connections between illness and wrongdoing. It is incredibly refreshing, and innovative, to find in a text as old as Tobit the attempt to move towards complexity and towards more positive norms. Ultimately, of course, the plentiful evidence for connecting corporeal dysfunction and wrongdoing demonstrates that the story of Tobit fails to change norms. But, as an example of theologically positive deviance it, nevertheless, may be thought of as a potential "source of innovation, energy, and change."

\footnotetext{
${ }^{38}$ Geoffrey D. Miller, "Raphael the Liar: Angelic Deceit and Testing in the Book of Tobit," Catholic Biblical Quarterly 74 (2012): 505.

${ }^{39}$ Anathea Portier-Young, "Alleviation of Suffering in the 'book of Tobit:' Comedy, Community, and Happy Endings," Catholic Biblical Quarterly 63, (2001): 41.

${ }^{40}$ McCracken, "Narration and Comedy," 405.

${ }^{41}$ Walls and Hoffman, "Exceptional Boards," 266.
} 


\section{Positive deviance in Job.}

An earlier example of a type of positive deviance away from the connection between bodily suffering and retribution emerges in Job. Many scholars have observed the similarities between Job's and Tobit's circumstances. ${ }^{42}$ A key example, is Portier-Young who systematically reviews and highlights the similarities in the views of retribution that are expressed in both. Similarly, Nowell argues that the problem in Tobit is created by 'the fundamental irony' not that "God is capricious but that God is free" and notes that "the same ironic situation is the problem in the Book of Job." ${ }^{43}$ Collins reaches a similar conclusion, arguing that "the problems ... that generate the core story of Tobit, are neither exile nor guilt, but the arbitrary suffering of innocent people, a phenomenon seldom acknowledged in the Hebrew Bible, with the notable exception of Job." 44 Additionally, Anderson comments that Tobit is "truly a Joban figure" wherein "his piety was not only unrewarded; it had become the occasion for a considerable trial." 45 Like Job, in Tobit's own estimation, he is innocent. As Soll observes "Tobit's sense of his own innocence is almost as robust as Job's." 46 As with Tobit's randomly being blinded, in Job inexplicable bodily suffering is pitted against the traditional wisdom of his friends in order to show the contest

\footnotetext{
42 In particular, there are clear correlations between the characterizations of Tobit and Job in the Testament of Job. In this work, which is closer to the Old Greek version of Job, Job is presented as overly charitable (Testament of Job 9-15; OG Job 31:31-37) to the extent that his charity exhausts his servants (Testament of Job 13:1-6). Like Tobit, the Testament of Job places a lot of importance of death and burial (Testament of Job 39:1-10; 40:6-14; 53:5-7). Trotter observes these similarities and argues that, "In both the Book of Tobit and the Testament of Job, the protagonist is presented originally as extremely pious through very special attention to his charity. Then, after unjustly suffering the loss of possessions and even of physical well-being, Tobit and Job are restored with the effect that they immediately return to life as usual: righteous living as manifested specifically through almsgiving." Jonathan R. Trotter, "The Developing Narrative of the Life of Job: The Implications of some Shared Elements of the Book of Tobit and the Testament of Job," Catholic Biblical Quarterly 77 (2015): 455.

Although not focused specifically on the connection between somatic difficulty and retributions, these observations are nevertheless helpful. This is because they demonstrate interpretations of the wider connections between Tobit and Job at an early stage.

${ }^{43}$ Nowell, Book of Tobit, 194.

${ }^{44}$ John Collins, "The Judaism of the Book of Tobit," in The Book of Tobit: Text, Tradition, Theology (Leiden: Brill, 2005): 29.

45 Gary Anderson, "Tobit as Righteous Sufferer," in A Teacher for all Generations; Essays in honor of James C. VanderKam, (Leiden; Boston: Brill, 2012), 496. 46 Soll, "Misfortune," 224.
} 
between what Newsom helpfully categorises as Job's and his friends' "moral imaginations." 47 The similarities, therefore, are striking especially with regard to the key hermeneutical question of somatic suffering, assumed deviance, and retribution.

However, one key difference between the characters Tobit and Job is their attitude. Although there is a clear absence of direct confession in Tobit as seen through his request for forgiveness for "inadvertent errors" and "unjust insults" there is an assumption that his blindness must be retribution for wrongdoing (Tob. 3:3, 6). The wrongdoing might be accidental, according to the logic of the Tobit's citing inadvertent errors but there is nevertheless some level of acknowledgement of wrongdoing, whether on his part or inherited from his ancestors. In contrast with Tobit, Job's protestations of innocence dramatically reject any agency or responsibility in causing his suffering. Instead of Job bearing responsibility, Job regularly refers to his body as the object of violent attacks from the deity (Job 6:4-13; 7:5, 15; 9:17-18; 16:6-17; 19:7-12; 30:16-31). As Hyun argues,

Job understands the suffering in his body as a medium to position God as his enemy. Specifically, Job confesses that the suffering caused by his body is the result of God's targeting his body for attack... Job proclaims what God has done to him/his body by saying, "for the arrows of the Almighty are in me, my spirit drinks their poison; the terrors of God are arrayed against me" (6:4).... Actually Job's confession in 6:4 reflects his perception of his present suffering. In other words, there is no other possible explanation for his suffering than that God is the aggressor. ${ }^{48}$

By shifting the agency away from Job and on to the deity, Job's lack of responsibility and therefore absence of wrongdoing is emphasised. Rather than Job's innocence being compromised, the problem is

\footnotetext{
${ }^{47}$ Carol A. Newsom, The Book of Job: A Contest of Moral Imaginations (Oxford: Oxford University Press, 2003).

${ }^{48}$ Seong Whan Timothy Hyun, Job the Unfinalizable: A Bakbtinian Reading of Job 1-11 (Leiden: Brill, 2013), 114.
} 
articulated on his lips as divine violence. The problem, as Job illustrates for his friends, is not that he is being punished for deviance. Instead, it is that the divine-human relationship is fundamentally menacing and sadistic. The push towards complexity in Job is clearly more pronounced than in Tobit. It is also an example of a type of positive deviance, similar to the progressive positive deviance we have seen in Tobit, away from the simplistic binary that "healthy = norm $/$ ill = deviance + stigma." This is helpful because it problematizes bodily sensation in a similar manner to the way medical Anthropologist Throop discovered when he examined the meanings associated with pain in yap. ${ }^{49}$ To recognise positive deviance here it is important to start from idea that norms are not always helpful. As we noted, through exploring Becker's work, it "social groups" who "create" deviance by "making the rules" and labelling those who do not obey them "as outsiders." ${ }^{50}$ Given the dominance of ideas connecting wrongdoing with somatic dysfunction in the Hebrew Bible and in many modern settings, it is remarkably progressive to find in Job a rejection of this norm.

A key part of the way positive deviance is evoked in the text is through reference to the deity. Simply put, the deity as discussed by Job and his friends acts in a very different way to the deity Yahweh in the book. Even the names of the deities that Job and his friends discuss rarely use the tetragrammaton, a title reserved mainly for the prologue and epilogue..$^{51}$ The referent group, or audience, are made aware of the deity's actions in sanctioning the Accuser to do anything with Job, save for killing him, in the knowledge that he threatens Job's "bone and flesh" (Job 2:6). As such, in Job dramatic irony functions as a key interpretive device revealing to audiences the limitations of Job's agency, but also problematizing Job's assumed responsibility in the estimation of his friends. Rather than acting in a

\footnotetext{
${ }^{49}$ Throop, Suffering and Sentiment.

${ }^{50}$ Becker, Outsiders, 8-9. Italics not in original.

51 The tetragrammaton only occurs once in the dialogues, on an occasion which may be an interpolation (Job 12:9; David J.A. Clines, Job 1-20 [Dallas: Word Books, 1989], 294). Otherwise, the deity is referred to as "שלוֹה "eloah," and more familiarly, שדי "the almighty," as well as "Hower, the tetragrammaton is used in the prologue and the whirlwind speeches regularly. For example, the term יהוה occurs in Job 1:6, 7, 8, 9, 12, 21; 2:1, 2, 3, 4, 6, 7, 9; 12:9; 38:1; 40:1, 3, 6; 42:1, 7, 9, 10, 11, 12.
} 
deviant way that brings retribution on himself, audiences are told from the outset that Job is "blameless" (תם) and "upright" (ישר). But this also implicates Yahweh rather heavily as a deviant character in the text. Similarly, Yahweh's responses to Job in the whirlwind speeches fail to answer his case directly. As such, Job's clipped and double-edged answers to Yahweh may function as another example of positive deviance in the text.

Job's response to Yahweh is a hermeneutical crux that is impossible to fully resolve. One angle that we take, to add to the well-trodden path of grappling with it, is to suggest that it picks up on the deviant language that Job uses in the dialogues when speaking about the deity, accusing the deity of violence. First, Job's "consoles himself" (assuming the reflexive sense of the niphal נחם) "concerning dust and ashes," or human frailty (Job 42:6). This picks up on the mention of dust and ashes in the depiction of a violent deity in Job 30:16-19, where dust and ashes refer to human frailty (cf. Gen. 18:27; Ezek. 27:30). Second, in his response to Yahweh, Job mentions things that are too "wonderful" (פלא) for him (Job. 42:3). Such wonders are usually positive in the Hebrew Bible, as they are on the lips of Job's friends (Job 5:9; 37:5, 14; Exod. 3:20; 34:10; Jos. 3:5; Judg. 6:13; 1 Chr. 16:9, 12, 24; 2 Chr. 26:15; Neh. 9:17; Ps. 71:19; 106:21-22). But for Job, they are negative and menacing, they are the deity's needless displays of strength (Job 10:16). Third, a linguistic and hermeneutical crux appears in relation to the term "reject" (מאס) in Job 42:6 because the verb lacks an object. ${ }^{52}$ When contextualised in relation to the dialogues, on Job's lips the verb מאס is negative (Job 7:5; 9:21; 10:3; 19:18; 31:1; 31:13). The word could, therefore, be understood as Job rejecting Yahweh's response by choosing to "submit" but in a very double-edged, deliberately polysemous, manner. Therefore, perhaps Job submits to Yahweh, but "but only grudgingly with a backhanded, and not so subtle, dose of rejection and disappointment." 53 . Or as Greenstein translates loosely, "This is why I am fed up." 54 Here in

\footnotetext{
${ }^{52}$ This could mean "waste away" but this term is not used in the qal and therefore perhaps unlikely.

${ }^{53}$ Southwood, Job's Body, 173.

${ }^{54}$ Edward L. Greenstein, Job: A New Translation (New Haven: Yale University Press, 2019), 185.
} 
the characterisation of Job we have a very radical example of positive deviance. The interesting thing about the way Job's situation is depicted here is that responsibility for his somatic distress is not sourced through the victim of said distress, but instead agency is attributed to Yahweh through the Accuser. But this is also positive deviance away from the idea of a deity who functions in a simplistic and mechanical way to reward the righteous and punish the wicked (cf. Ps. 1-2). It is also an example of positive deviance away from the idea of a deity who would be held to account by simplistic notions of causality. Instead, the positive deviance creates space for the referent group, or audience, to reach a more mature appreciation of Yahweh's immeasurable freedom, grandeur, and irreducibility. It also creates space, through the example of Job's reaction, for a human response to Yahweh to be frustration when he does not conform to expectations and norms.

Another important aspect of the manner in which Job rejects the idea of assuming corporeal distress must be some sort of retribution for wrongdoing is though the ironic reuse of language about the deity's responsibility for his distress. Through making the deity the aggressor Job resists the traditional assumptions found within many laments. For example, usually in the Psalms, enemies are depicted using theriomorphic metaphors as predators from which Yahweh can save the Psalmist (Ps 7:1; 17:12;22:12). Yet on many occasions, Job's language makes the deity the predatory animal from which there is no escape (Job 16:7-9). Similarly, turning the assumptions embedded within lament on their head, Job calls upon the earth not to cover his blood (Job 16:9). Newsom observes that the rhetoric of lament is "configured as legitimate punishment" by Job since "by echoing the story of Abel's blood crying out from the ground (Gen. 4:10; cf. also Isa. 26:21; Ezek. 24:7-8), [he] reconfigures it as murder." 55 Turning the logic embedded within Job's friends' assumptions about his deviance on to the deity through metaphors of divine violence is, therefore, a key device of resistance to the idea of connecting bodily dysfunction with retribution and wrongdoing. 
Thus, an example positive deviance away from a simplistic theological premise. This is because the audience, or referent group, are able to gain a more nuanced insight into Job's situation since they have been made aware through the prologue that Job is not responsible for his physical condition. To use an analogy from the theoretical material discussed above, it is impossible for the audience to think that Job is "careless, or immoral lacking in self-respect," an assumption often made about those who are obese, because dramatic irony prevents that conclusion. ${ }^{56}$

Resisting the idea of retribution is a key part of the dialogues between Job and his friends. As has been argued elsewhere, the advice that Job's friends provide for him is moralising, that is "language and advice, what is meant is judgemental communication - speech emphasising personal responsibility and incriminating assumptions embedded within advice." ${ }^{57}$ Throughout the dialogues, Job's friends inadvertently (through moralising advice), and sometimes openly, accuse him of having brought his troubles upon himself through his failure to admit wrongdoing. Sometimes their advice even echoes the first thing that audiences are told about Job, namely that he is innocent and upright. For example, Eliphaz asks "who that was innocent (נקי) ever perished, and where were the upright (ישר) cut off?" (Job 4:7). Likewise, Bildad asserts that "if you were pure (זר) and upright (ישר), then surely he would cause himself to wake for you" and suggests that "God will not reject a blameless (תם )man" (Job 8:6, 20). Zophar goes even further, suggesting that although Job says his "insights are pure (זך)" he must be wrong: how could Job possibly know given the magnitude of the Almighty? Therefore, Zophar suggests Job should "prepare his heart and stretch out his hand towards Shaddai" (Job 11:4, 13). The assumption that Job has brought his condition of bodily dysfunction upon himself is particularly insidious. Even with the assistance of modern biomedicine, "professional prejudice is particularly strong where patients are thought to have brought illness upon themselves or

56 Tomlinson, “Power," 160.

${ }^{57}$ Southwood, Job's Body, 1. 
contributed to it." 58 Given the negative assumptions that accompany any suggestion that bodily dysfunction has been instigated by the patient themselves, Job's predicament becomes all the more dangerous. Not only must the character manage the somatic state he describes, he must also negotiate his way around the stigma that accompanies it. Therefore, a "second illness" namely stigma complicates an already difficult situation. ${ }^{59}$ However, in the dialogues, Job's resistance to the moralizing advice of his friends only infuriates them, partly because for them the link between bodily dysfunction, deviance, and retribution is so robust, as demonstrated in the introduction.

By making the audience aware of the fact that Job is innocent from the outset, the advice provided, at length, to Job by his friends is set up in a way that causes audiences to question the strength of the connection between bodily pain, deviance, and retribution. This space is an example of positive deviance. Even modern referent groups find the deviance away from the binary "healthy $=$ norm $/$ ill = deviance + stigma" positive. For example, Claassens points out Job "offers an excellent example of the stereotypes regarding disability" because "one repeatedly finds the notion that disability or disease is the direct consequence of sin. Particularly in the friends' speeches, one hears the refrain that Job must have done something wrong to warrant his predicament." ${ }^{60}$ Part of the reason that Job has such an enduring appeal is because of its mimetic qualities in relation to the idea of retribution and deviance. As Lyons argues,

Even today, victims of disaster really do speak as Job speaks, creating explanation after explanation in an attempt to provide a rationale for what has befallen them. Onlookers really do point their fingers and explain disaster as divine judgment. People really do argue in the way Job and the

\footnotetext{
${ }^{58}$ Tomlinson, "Power," 160.

${ }^{59}$ Beate Schulze and Matthias C. Angermeyer, "Subjective Experiences of Stigma. A Focus Group Study of Schizophrenic Patients, their Relatives and Mental Health Professionals," Social Science \& Medicine 56 (2003): 299-312.

${ }^{60}$ L. Juliana M. Claassens, “Countering Stereotypes: Job, Disability, and Human Dignity," Journal of Religion, Disability \& Health 17 (2013): 173.
} 
friends do, accusing and misrepresenting each other, revelling in the triumph of successfully wielding an opponent's words as weapons. In short, the book of Job is perceived as relevant because it reflects universal human experience. ${ }^{61}$

While sometimes the question of responsibility is helpful with respect to bodily dysfunction, for example through encouraging healthy behaviours, the blunt assumption that anybody who is ill must deserve to be so assigns a level of agency and control to people that is out of proportion with reality. This is why Job's experience "may often appear at times of crisis in today's patients." 62 Allowing space for referent groups to uncouple the tight connection between somatic dysfunction and retribution for wrongdoing is, as noted, progressive. This is especially the case given the all too common connections that are made so regularly in present times between illness and deviance, as demonstrated in the introduction. We noted the prevalence of the tendency to suppose, without consideration, that people are to blame for their conditions. Therefore, like Tobit, in Job the way that retribution is presented is positive deviance away from a simplistic theology of rights and rewards. Though in Job the resistance to connecting bodily breakdown with retribution is presented more radically than in Tobit. Sadly, however, like Tobit, although Job offers a potential "source of innovation, energy, and change" the movement from positive deviance to positive norms is not established. ${ }^{63}$ (Walls and Hoffman 2013:266). Instead, the connection persists on into the New Testament with very clear statements of retribution such as the question posed by the disciples "Rabbi, who sinned, this man or his parents, that he was born blind?" or the citing of $\sin$ as the reason the paralytic's condition (John 9:2; Matt. 9:1-8; Mark 2:1-12; Luke 5:17-26).

\footnotetext{
${ }^{61}$ Michael A. Lyons, "I Also Could Talk as You Do" (Job 16:4): The Function of Intratextual Quotation and Allusion in Job," in Reading Job Intertextually (New York: Bloomsbury, 2013): 177.

${ }^{62}$ Ilan Kutz, "Job and his 'Doctors:' Bedside Wisdom in the Book of Job," BMJ, 321 (2000): 1615.

${ }^{63}$ Walls and Hoffman, "Exceptional Boards," 266.
} 


\section{Conclusion}

In this article we recognised the similarities between Tobit and Job in terms of the predicament of the main protagonists both of whom experience bodily dysfunction. Tobit is blinded through a random act of bird droppings and Job suffers the impact of the Accuser striking his skin and flesh. Both characters attempt to understand what happened, Tobit through assuming retribution, Job through protesting his innocence. In Tobit's case, audiences are invited to question Tobit's own conclusions about his predicament. This example of positive deviance emerges through Tobit's characterisation, wherein on many occasions dramatic irony allows audiences to see the limitations of Tobit's eager piety. Similarly, dramatic irony functions in Job to set each of his friends up as a parody of the wise councillor. Audiences, or the referent group, are told that Job is innocent and this undermines the friends' advice. In both cases the heart of the problem that audiences are invited to consider is the strength of the connection between bodily dysfunction, deviance, and retribution. In both cases, bodily dysfunction has nothing to do with actions of the main protagonist. Both are examples of positive deviance away from a failed norm, which ultimately do not result in a more positive norm. 